ZOOLOGIA 30 (3): 317-323, June, 2013

http://dx.doi.org/10.1590/S1984-46702013000300009

\title{
Description and phylogenetic position of a new species of Metarthrodes (Opiliones: Gonyleptidae: Caelopyginae) from Bahia, northeastern Brazil
}

\author{
Amanda Cruz Mendes ${ }^{1} \&$ Carla Martinho de Lima Barros ${ }^{1}$
}

\begin{abstract}
${ }^{1}$ Departamento de Invertebrados, Museu Nacional, Universidade Federal do Rio de Janeiro. Quinta da Boa Vista, São Cristóvão, 20940-040 Rio de Janeiro, RJ, Brazil.E-mail: amanda.mendes@gmail.com; carlamlbarros@gmail.com
\end{abstract}

\begin{abstract}
We describe Metarthrodes oxum sp. nov. from Camacan, state of Bahia, Brazil, the second species of Caelopyginae described from the state, after Metarthrodes xango Pinto-da-Rocha, 2002. Metarthrodes oxum sp. nov. can be recognized by the presence of a pair of white spots on area I, white C-shaped stripes on lateral grooves of area III, posterior margin with transverse white stripe, grooves of mesotergal areas well-marked, posterior margin of dorsal scute slightly concave, and medial third of femur IV of male with three large and spiniform retrolateral tubercles. We tested the generic placement of the new species via cladistic analysis. Metarthrodes oxum sp. nov. clustered within Metarthrodes, forming a clade with M. pulcherrimus (Mello-Leitão, 1931), M. nigrigranulatus Roewer, 1913 and M. longipes (Soares, 1945), which was unresolved in the consensus cladogram of the 72 optimal trees found, and is supported by the following synapomorphies (all present in males only): trochanter IV with long internal apophysis; retrolateral submedian tubercle on femur IV, and a pair of white spots near the groove. We also provide an updated identification key for the species of Metarthrodes.
\end{abstract}

KEY WORDS. Grassatores; harvestmen; Laniatores; taxonomy; Neotropical Region.

The Caelopyginae comprises 30 species grouped into nine genera, and includes medium-sized gonyleptids, usually yellow to greenish, with white spots on the dorsal scute. Species in this group are highly endemic, and are found in the Atlantic Forest of eastern Brazil, from the state of Bahia, in the North, to the state of Santa Catarina, in the South (PINTO-DA-Rocha 2002, DaSilva \& PinTo-Da-Rocha 2012).

Caelopyginae forms a clade with Gonyleptinae, Sodreaninae, Progonyleptoidellinae and Hernandariinae (KURY 1992, 1994, 1995, Pinto-Da-Rocha 2002, DaSilva \& Pinto-DaRocha 2010, Pinto-da-Rocha \& Bragagnolo 2010, Caetano \& Machado 2013). Those closely related Gonyleptinae-like subfamilies (referred to as K92 by CAETANO \& MACHADO 2013: 8) are characterized by having a deep parabolic cleft on the distal margin of the ventral plate of the penis, which is pyriform and bears extremely developed basal lobes that are dorsally directed (instead of laterally) (KunY 1992, 1994, 1995, KuRY \& PinTO-DARocha 2007). The monophyly of clade K92 has been corroborated by various cladistic analyses, and additional morphological synapomorphies have been found for the group: characters in the pedipalpus, the armature of the anterior margin of the dorsal scute and the armature of femur IV of the male (PINTODa-Rocha 2002, DaSilva \& Pinto-Da-Rocha 2010, Pinto-Da-Rocha \& Bragagnolo 2010). Moreover, defensive behavioral characters and the chemical composition of the scent gland secretions also support clade K92 (CAETANo \& Machado 2013).
PINTO-DA-Rocha (2002) revised the Caelopyginae, provided a phylogenetic hypothesis for it, and generated a classification congruent with his phylogeny. Recently, DaSilva \& PinTo-DARосна (2012) described two new species in Caelopyginae, which they placed in Pristocnemis Koch, 1839 and Thereza Roewer, 1943, after a morphological phylogenetic analysis based on PINTO-DA-RochA's (2002) previous work.

Before this contribution, Metarthrodes Roewer, 1913 included nine species, distributed in the Atlantic Forest from the state of Bahia to the state of São Paulo (with a questionable record of M. nigrigranulatus Roewer, 1913 from the state of Paraná) (PINTO-DA-Rocha 2002). In this paper we describe an additional species in Metarthrodes. The new species is also the second known record of Caelopyginae from Bahia, Brazil. In order to confirm the phylogenetic position of the new species, we performed a parsimony analysis using morphological data from Pinto-Da-Rocha (2002) and DaSilva \& Pinto-Da-Rocha (2012).

\section{MATERIAL AND METHODS}

The original photographs were taken with a Sony Cybershot DSC-V1 attached to an Olympus dissecting microscope. In order to obtain images with a greater depth of field, we used focus stacking, a digital image processing technique which combines multiple images taken at different focus distances using 
the software package CombineZ, version CombineZP (Hadley 2012). We also made schematic illustrations directly from the photographs, or using a camera lucida. We followed the morphological nomenclature of PINTO-DA-Rocha (2002) and adaptations of DASILVA \& PINTO-DA-Rocha (2012).

The collections mentioned in this paper and their respective acronyms are: Museu de Zoologia, Universidade Federal da Bahia, Salvador, Brazil (MZ-UFBA); Museu Nacional, Universidade Federal do Rio de Janeiro, Brazil (MNRJ). All measurements are given in millimeters $(\mathrm{mm})$. The tarsal formula is given as follows: I, II, III, IV, with numbers for legs I-II followed by the distitarsal count within parentheses.

In order to test the generic placement of our new species, we added Metarthrodes oxum sp. nov. to the matrix of PINTO-DARосна (2002), with Thereza murutinga DaSilva \& Pinto-da-Rocha, 2012, Pristocnemis caipira DaSilva \& Pinto-da-Rocha, 2012, and the modifications proposed by DaSilva \& Pinto-Da-Rocha (2012) (see Parsimony analysis section). We performed an heuristic search with multiple random addition sequences $(1,000$ replicates) saving up to 1,000 trees per replication, swapping trees with TBR using the program TNT (GolobofF, FarRis \& Nixon 2008). Characters were treated as unordered and equally weighted. We evaluated branch-support by absolute Bremer support (BREMER 1994), relative Bremer support (RBS, relative fit difference; GoLoBoff \& FARRIs 2001), and bootstrap (Felsenstein 1985), also implemented by TNT. The Bremer support was calculated by searching for suboptimal trees, increasing the number of suboptimal trees in steps. The bootstrap analysis was performed with 3,000 replicates with tree bisection-reconnection branch swapping. We studied the distribution and optimization of the characters on the optimal trees obtained using WINCLADA (Nixon 2002).

\section{RESULTS}

\section{Taxonomy}

\section{Key to the species of Metarthrodes (adapted from Pinto-Da-Rocha 2002)}

1. Pair of armature of area III blunt (Figs 1 and 5; PINTO-DARocha 2002: figs 34 and 35)

1'. Pair of armature of area III spiniform (PINTO-DA-Rocha 2002: figs $33,36-43,187$, and 190)

2. Prosoma with pair of white spots behind ocularium (Figs 1 and 5; PINTO-DA-Rocha 2002: fig. 34); trochanter IV with large retrolateral tubercle (same length as the trochanter width, Figs 1 and 6; Pinto-DA-Rocha 2002: fig. 92); dorsal anal operculum unarmed (Fig. 4) ............................................ 3

2 '. Dorsal scute with large white spot from anterior to posterior margin (PINTO-DA-Rocha 2002: fig. 35); trochanter IV with short retrolateral tubercle (smaller than width of the trochanter); dorsal anal operculum with large tubercle (PINTO-DA-Rocha 2002: fig. 35) .....

M. albotaeniatus (Mello-Leitão, 1942)
3. Lateral grooves of area III with pair of white, C-shaped stripes (resembling parentheses), posterior margin with transverse white stripe (Figs 1, 3, and 5); grooves of mesotergal areas well marked (Figs 1 and 3); posterior margin of dorsal scute slightly concave (Figs 1 and 5) M. oxum sp. nov.

3'. Grooves of area III without pair of white spots or white Cshaped stripes, posterior margin without white stripe; grooves of mesotergal areas faint; posterior margin of dorsal scute strongly concave (PINTO-DA-RocHA 2002: fig. 34) ......

M. nigrigranulatus Roewer, 1913

4. Dorsal anal operculum with one tubercle or spine (PINTO-DARосHA 2002: figs 40-41 and 190) 5

4'. Dorsal anal operculum unarmed ..................................... 6

5. Femur IV long (five times length of dorsal scute) and smalltuberculate (PINTO-DA-Rocha 2002: fig. 180)

M. longipes (Soares, 1945)

5 '. Femur IV shorter (less than three times length of dorsal scute) and with large retrolateral tubercles (PINTO-DA-RocHA 2002: figs 91 and 190) ......... . pulcherrimus (Mello-Leitão, 1931)

6. Coxa IV with small retrolateral apical apophysis (PINTO-DARосна 2002: figs 36, 39-40, and 42) or unarmed (Pinto-daRocha 2002: fig. 33); posterior margin slightly concave (PinTo-DA-Rocha 2002: figs 33 and 36)

6 '. Coxa IV with retrolateral apical apophysis larger than dorsal (PINTO-DA-Rocha 2002: figs 37 and 38); posterior margin strongly concave (PINTO-DA-RochA 2002: figs 38 and 187) 9

7. Coxa IV with small retrolateral apophysis (PINTO-DA-RochA 2002: figs 36, 39-40, and 42); dorsoapical apophysis curved in all extension; prosoma without white spots ............... 8

7'. Coxa IV without retrolateral apophysis (PINTO-DA-Rocha 2002: fig. 33); dorsoapical apophysis curved only apically; prosoma with one pair of white spots

M. bimaculatus Roewer, 1913

8. Femur IV straight, extremely large, with one dorsal row of large tubercles (PINTO-DA-RochA 2002: fig. 89); anterior margin of dorsal scute with one pair of short tubercles (Pinto-Da-Rocha 2002: fig. 39) M. leucopygus Roewer, 1913

8'. Femur IV curved, moderately large (PINTO-DA-Rocha 2002: fig. 93), with short dorsal tubercles; anterior margin of dorsal scute with 1 pair of large tubercles (PINTO-DA-Rocha 2002: fig. 39) M. hamatus Roewer, 1931

9. Apical internal apophyses of coxa IV convergent (PINTO-DARосна 2002: figs 38 and 187), area III smooth behind spines (PinTO-DA-Rocha 2002: fig. 38)

M. laetabundus (Sørensen, 1884)

9'. Apical internal apophyses of coxa IV slightly divergent (PINTO-DA-Rocha 2002: fig. 37), area III with tubercles behind spines (PINTO-DA-Rocha 2002: fig. 37)

M. xango Pinto-da-Rocha, 2002 

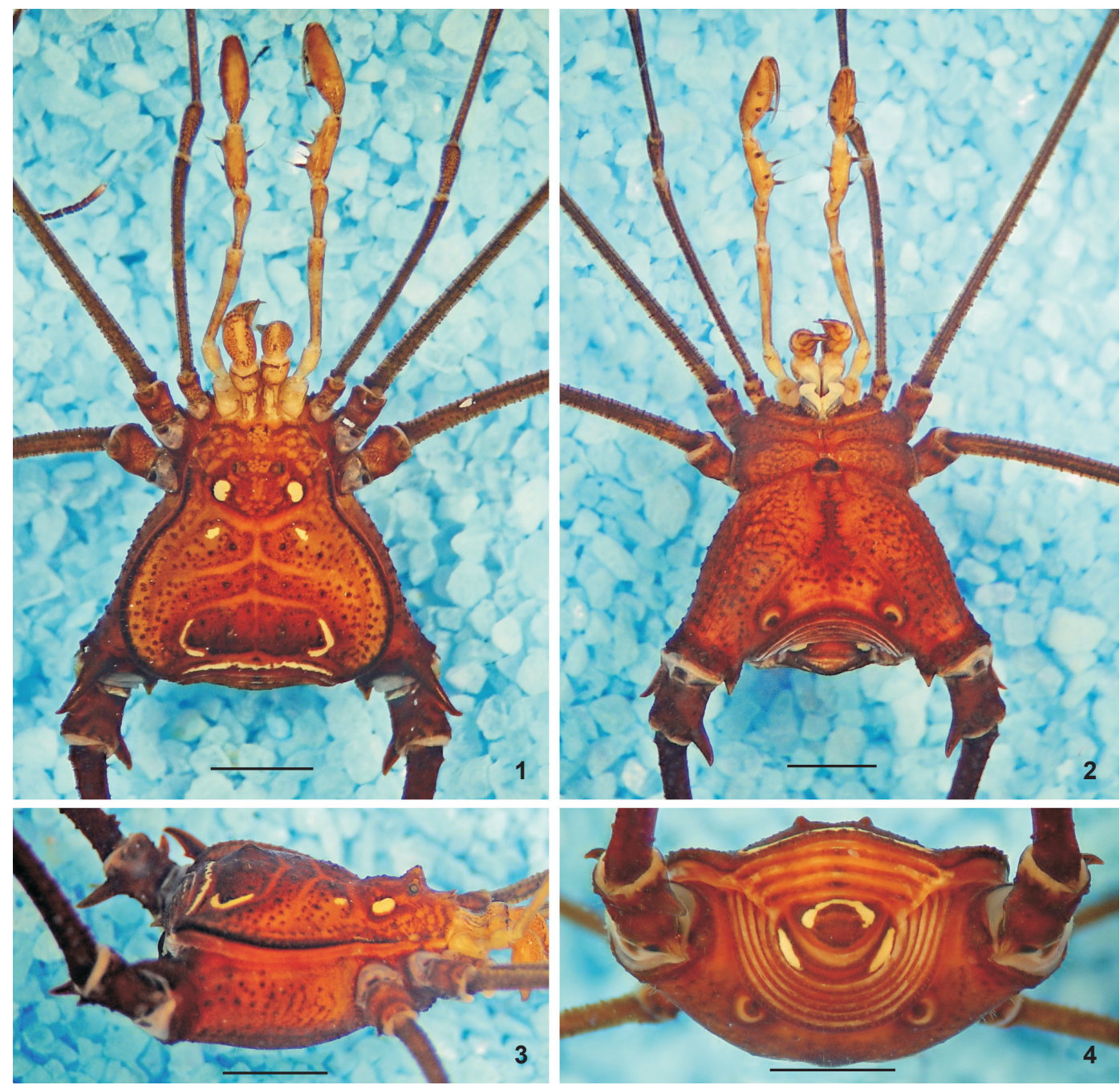

Figures 1-4. Metarthrodes oxum sp. nov., male holotype, habitus: (1) dorsal view; (2) ventral view; (3) lateral view; (4) posterior view. Scale bars: $2 \mathrm{~mm}$.

\section{Metarthrodes oxum sp. nov. \\ Figs 1-19}

Holotype: Brazil, Bahia: Camacan (Serra Bonita, $15^{\circ} 23^{\prime} \mathrm{S}$ 39³ $\left.33^{\prime} \mathrm{W}\right)$, male, 20.II.2009, T.J. Porto leg., UFBA Opi 48.

Diagnosis. Resembles $M$. nigrigranulatus by possessing a blunt armature pair in area III and a pair of white spots on the prosoma, behind the ocularium; differs from it by having the posterior margin with transverse white stripe, grooves of mesotergal areas well-marked, posterior margin of dorsal scute only slightly concave and male femur IV with three large and spiniform retrolateral tubercles on medial third.

Differs from other species by the brownish body (yellow or green in other species), and a pair of C-shaped white stripes on lateral grooves of area III.
Description. Male holotype. Measurements. Prosoma length 2.3; prosoma maximal width 3.5, opisthosoma length 4.1, opisthosoma maximal width 6.1. Measurements of appendages as in Table I.

Table I. Appendage measurements of the male holotype of Metarthrodes oxum sp. nov.

\begin{tabular}{lcrrrrrrr}
\hline Appendage & Trochanter & Femur & Patella & Tibia & Metatarsus & Tarsus & Claw \\
\hline Pedipalpus & 0.8 & 3.0 & 1.2 & 1.5 & - & 2.1 & 1.7 \\
Leg I & 0.8 & 5.7 & 1.3 & 3.6 & 6.1 & 2.6 & - \\
Leg II & 1.0 & 13.9 & 1.5 & 9.6 & 12.2 & 8.0 & - \\
Leg III & 1.2 & 9.9 & 1.4 & 4.9 & 9.9 & 4.0 & - \\
Leg IV & 1.4 & 14.6 & 2.2 & 8.1 & 17.8 & 5.2 & - \\
\hline
\end{tabular}


Dorsum (Figs 1, 3, and 5-7). Anterior margin of dorsal scutum with two spiniform parallel median tubercles on frontal hump. Ocularium with pair of small tubercles. Carapace with disperse tubercles lateral and posterior to the ocularium. Mesotergum with tubercles irregularly distributed. Area I divided in left right halves by a median longitudinal groove. Areas I-III each with median pair of round tubercles, larger in area III. Posterior margin slightly concave. Posterior margin and free tergites each with a row of small tubercles. Dorsal anal operculum unarmed, with sparse granules. Venter (Figs 2 and 6). Coxae I-II with transversal rows of setiferous tubercles, the median row with larger tubercles. Coxae III-IV with small setiferous tubercles irregularly distributed. Posterior margin of stigmatic area and free sternites with a row of granules. Ventral anal operculum unarmed. Chelicerae (Figs 1-3 and 5-7). Segment I with small setiferous prolateral tubercle on bulla; II-III with three and five teeth, respectively. Pedipalpi (Figs 1, 2, 8, and 9). Long and thin. Coxa smooth. Trochanter with small setiferous ventral tubercle. Femur and patella smooth. Tibia mesal Iii; ectal iI(Ii). Tarsi mesal ectal II. Legs (Figs 1-3, 5, 6, and 10-14). Coxae I-II with one dorso-anterior tubercle; III smooth; IV tuberculate with prolateral apical apophysis directed backwards, 1.5 longer than retrolateral. Trochanters I-III with scattered ventral tubercles; IV with basal prolateral blunt tubercle and sub-apical retrolateral spiniform apophysis, twice as long as prolateral. Femora I-III straight and with small tubercles; IV sub-straight in dorsal view and slightly curved in lateral view; with one dorsal row of tubercles, larger and conical on medial third; one ventral row of tubercles, increasing in size and taking a more retrolateral position towards apex, the 3-4 distal tubercles larger and spiniform; one prolateral row of tubercles on proximal half, and one prolateral row of blunt tubercles beginning at middle, 3 distalmost tubercles larger and spiniform; one retrolateral row of tubercles, three largest and spiniform on medial third and one apical spiniform. Patellae IIII with small ventral tubercles; patella IV tuberculate, with long spiniform ventral tubercles. Tibiae I-III smooth; tibia IV densely tuberculate on ventral region. Tarsal counts: 8(3), 16-17 (4), 16-17, 16-17. Color (in ethanol) (Figs 1-4). Dorsal scute brownish-yellow, covered by dark-brown tubercles, with dark-brown reticulation in carapace and mesotergal areas, darker in area III. Legs with brownish-yellow background, with strong darkbrown reticulation. Chelicerae and pedipalpi yellow, chelicerae with dark-brown reticulation and pedipalpi with dark-brown reticulation on femora, patellae, tibiae and tarsi. Prosoma with pair of white spots behind ocularium. Mesotergal area I with paramedian pair of white spots. Area III with pair of C-shaped white stripes on lateral grooves of area III (resembling parentheses). Posterior margin with transversal white stripe; dorsal anal operculum with anterior white arch stripe, ventral anal operculum with pair of white spots. Penis (Figs 15-18). Distal part of truncus with dorsal part enlarged and subapical ventral deep cleft, giving a sinuous aspect in lateral view to the penis.
Ventral process of glans with cleft, without prominences. Stylus short and thick, without microsetae apically. Ventral plate thick, densely covered by ventral microsetae and with short, U-shaped cleft on apical margin. Three pairs of distal setae, located apically, and five pairs on basal lobe (basal long).

Female. Unknown.

Distribution. The species is known only from the type locality, an area of evergreen alluvial forests (IBGE 2012). The state of conservation of the vegetation in Serra Bonita varies, with some areas apparently untouched, but also including others in different stages of ecological succession, and areas where cocoa is cultivated (Amorim et al 2009).

Etymology. Oxum is an Orisha (minor god) from the Yoruba religion, whose pantheon (set of gods) was incorporated by Afro-Brazilian religions such as the Candomblé and Umbanda, religions widely practiced in Bahia. Oxum is represented as a charming female deity, who reigns over lakes and rivers. We chose Oxum in reference to the other species of Caelopyginae from Bahia, Metarthrodes xango, because Oxum is also one of the spouses of Xango.

Additional specimens examined. Garatiba bocaina Pintoda-Rocha, 2002: Brazil, São Paulo: Bananal (Fazenda Albion, $1300 \mathrm{~m}$ a.s.l., on leaves of understory, at breast height), female paratype, 23.IX.1989; F.B. Pontual leg., MNRJ 06531. Metarthrodes albotaeniatus (Mello-Leitão, 1942): Brazil, Espírito Santo: (Santa Teresa), male holotype, A. Ruschi leg., MNRJ 05125. Metarthrodes bimaculatus Roewer, 1913: BrazIL, Espírito Santo: (Colatina, Rio São José), 2 males, Rosa, M. leg., MNRJ 55088 (syntypes of Metarthrodes rosai Mello-Leitão, 1942). Metarthrodes laetabundus (Sørensen, 1884): Brazil, Rio de Janeiro: (Santa Maria Madalena, PARES do Desengano, Morumbeca, 1000-1400 m a.s.l.), 1 male, 4 females, 13-17.V.2008, A. Chagas-Jr, A.B. Kury, C. Sampaio \& T. Moreira leg., MNRJ 02100. Metarthrodes leucopygus Roewer, 1913: BraziL, Espírito Santo: (Santa Teresa), 1 male, A. Ruschi leg., MNRJ 05128 (holotype of Varzellinia leucopyga Mello-Leitão, 1942). Metarthrodes longipes (Soares, 1945): Brazil, São Paulo: (Ubatuba, Parque Estadual da Serra do Mar, Núcleo Picinguaba, Trilha do Corisco), 1 male, 5 females, 23-26.VI.1997, R.L.C. Baptista leg., MNRJ 5486. Metarthrodes nigrigranulatus Roewer, 1913: BrazIL, Rio de Janeiro: Petrópolis (Morro de Caxambu), 2 males, 1 female, R. Arlé leg., MNRJ 42462 (syntypes of Heterampheres variabilis Mello-Leitão, 1935). Metarthrodes pulcherrimus (Mello-Leitão, 1931): BrAZIL, São Paulo: Salesópolis (Boracéia), 1 male, 1 female, 22.X.1995, S.A. Vanin leg., MNRJ 05687. Metarthrodes xango Pinto da Rocha, 2002: Brazil, Bahia: Gandu (Fazenda São Rafael, Cocoa plantation, CEPLAC R3144), male holotype, 20.IX.1970, MNRJ 05643.

\section{Parsimony analysis}

The character states for the new species in the matrix of PINTO-DA-Rocha (2002) are as follows: Metarthrodes oxum sp. nov. ?000011110 01?1000011?1101000110101012112 1000011010 10011000 . 

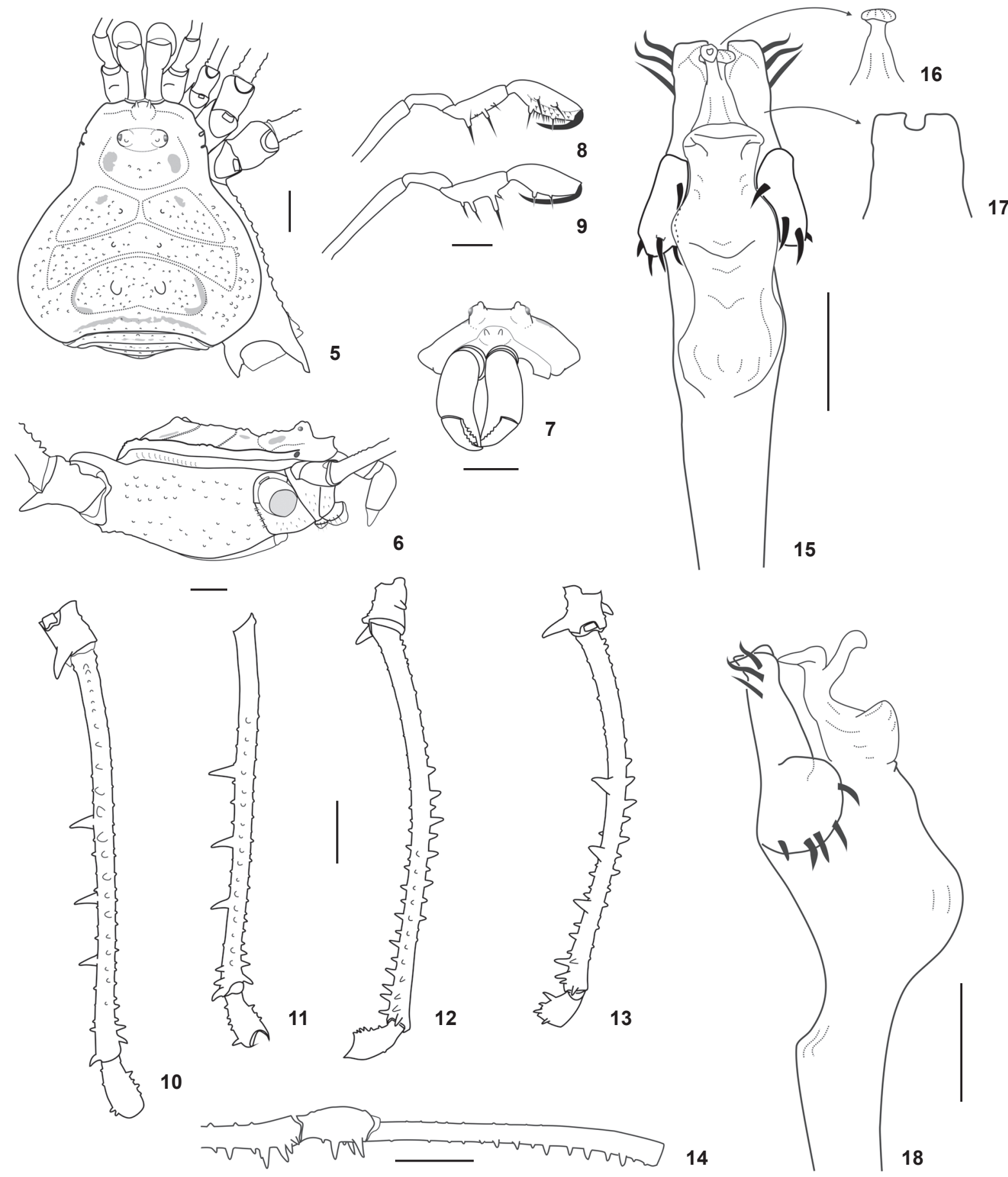

14

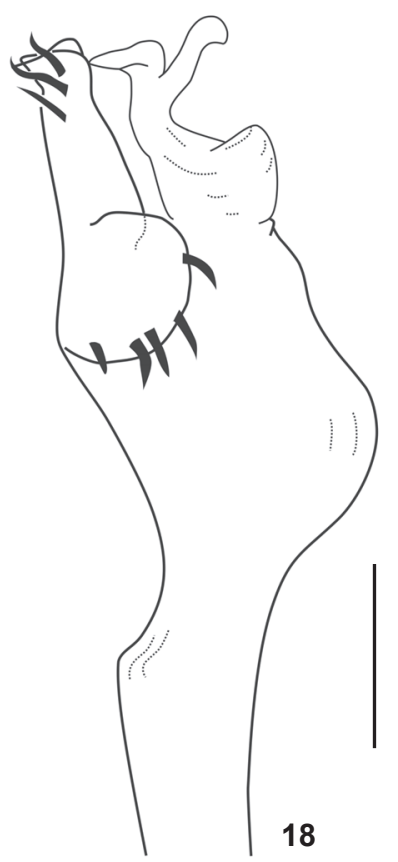

Figures 5-18. Metarthrodes oxum sp. nov., male holotype: (5) habitus, dorsal view; (6) lateral view; (7) frontal view; (8) left pedipalpus distal femur to tarsus, mesal view; (9) right pedipalpus distal femur to tarsus, ectal view; (10-14) leg IV: (10) trochanter, femur, patella of right leg, dorsal view; (11) femur and patella of left leg, ventral view; (12) trochanter, femur and patella of left leg, prolateral view; (13) trochanter, femur and patella, retrolateral view; (14) apex of femur, patella and tibia of right leg, retrolateral view; (15-18) distal part of penis: (15) dorsal view; (16) detail of ventral process; (17) detail of dorsum of ventral plate; (18) lateral view. Scale bars: 5-9, 15$18=1 \mathrm{~mm} ; 10-14=2 \mathrm{~mm}$. 
Notes on the codification: We coded M. oxum sp. nov. as having state 0 for character 35, "Truncus of penis without subapical projection (PINTO-DA-Rocha 2002: 375). However, the ventral deep cleft in the truncus (Fig. 18) gives it a sinuous aspect, similar to the species that have a subapical projection: M. laetabundus, M. xango and Pristocnemis perlatus (Giltay, 1928). However we propose a new character to account for this similarity in the male genitalia: Character 59. Male genitalia, distal part, ventral subapical cleft: (0) absent; (1) present. Metarthrodes laetabundus, M. oxum sp. nov., M. xango and Pristocnemis perlatus were coded as "present"; the remaining terminal taxa were coded as "absent".

We also emended state 1 of character 51 (spots on area III of male; PINTO-DA-Rocha 2002: 377) to "with pair of rounded or C-shaped white spots near groove IV". The spots in M. oxum sp. nov. are C-shaped (resembling parentheses), but their position on the groove suggests that they are homologous with the rounded spots.

The phylogenetic analysis resulted 72 equally parsimonious trees (Length $=193$ steps, Consistency Index $=0.39$, Retention Index $=0.74)$. The topology of the strict consensus cladogram (Fig. 19) is very similar to the consensuses obtained by Pinto-DA-Rocha (2002) and DaSilva \& Pinto-DA-Rocha (2012). All genera were recovered as monophyletic. Metarthrodes was the best supported genus (Bremer $=3$, RBS $=47$, Bootstrap $=71 \%$ ), with four non-ambiguous synapomorphies: external apical apophysis of coxa IV of male with basal tubercle (character 20, state 1 ); stylus short and thick (character 36 , state 1 ); cleft on ventral process of stylus (character 38 , state 1 ); prominences of ventral process absent (character 40, state 2). Metarthrodes oxum sp. nov. clustered within Metarthrodes, forming a monophyletic unit with M. pulcherrimus, M. nigrigranulatus, and M. longipes, with 3/43/ $50 \%$ of Bremer/RBS/Bootstrap support, and by the following nonambiguous synapomorphies: long internal apophysis on male trochanter IV (character 23, state 1); retrolateral submedian tubercle on femur IV of male (character 29, state 1) and male with a pair of white spots near groove IV (character 51, state 1).

The addition of M. oxum sp. nov. caused the relationships among some species of Metarthrodes to differ from the previous analysis (PINTO-DA-Rocha 2002). However, the overall topology obtained by us is not only congruent with DASILVA \& PinTo-DA-Rocha (2012), but it also adds more resolution to it. We have also recovered a basal M. bimaculatus and the clade $M$. laetabundus + M. xango. However, in our topology, M. hamatus appears as the sister-group of M. nigrigranulatus $+M$. longipes + M. pulcherrimus, and M. leucopygus as sister-group of $M$. albotaeniatus, both clades with very low support (Fig. 19). We recovered the group $M$. nigrigranulatus $+M$. longipes $+M$. pulcherrimus, as in those previous analyses, but with the addition of M. oxum sp. nov. We could not elucidate the relationship among those species. As DaSilva \& Pinto-Da-Rocha (2012) had already stressed, we reinforce the need for new studies on phylogeny of Caelopyginae, using new character systems.

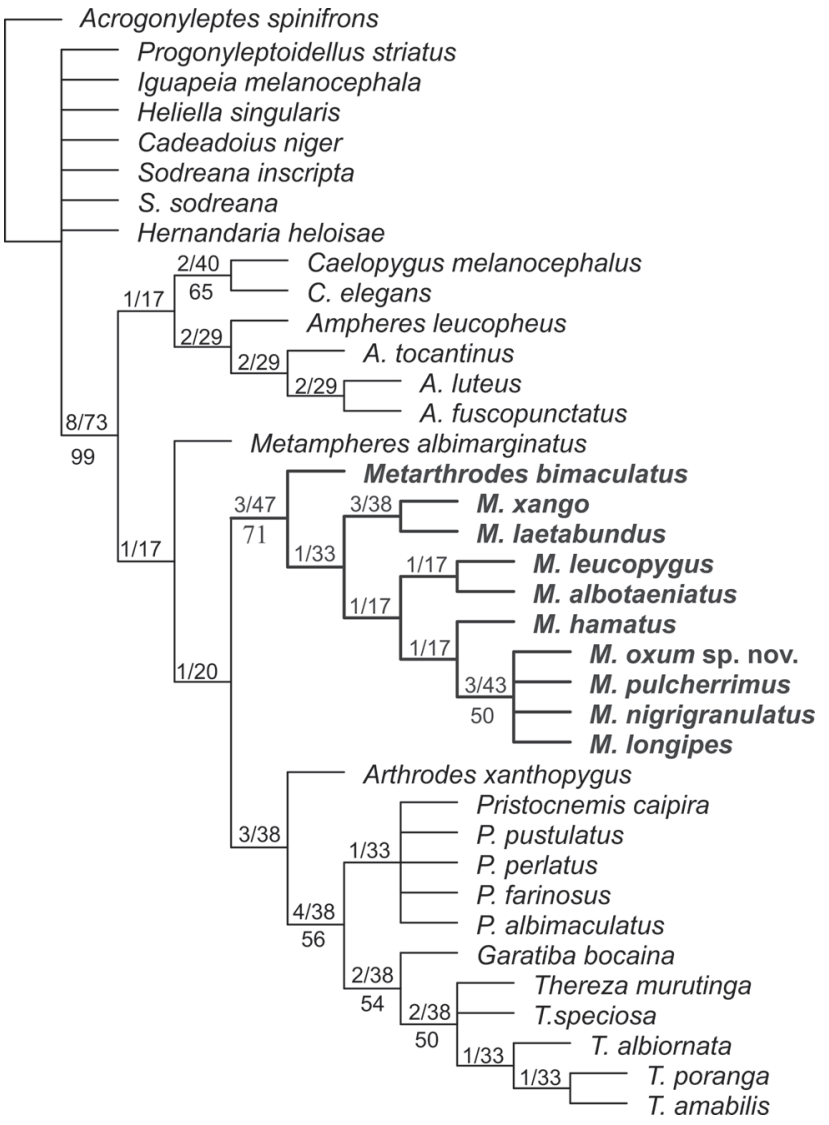

Figure 19. Strict consensus of the 72 most parsimonious trees (Length = 193 steps; Consistency Index = 0.39; Retention Index = 0.74 ) obtained with heuristic search, characters unordered and equally weighted. Clade support is indicated above (absolute/relative Bremer support values) and below (bootstrap proportions, only shown when support is above $50 \%$ ) branches.

\section{ACKNOWLEDGEMENTS}

This study was supported by grant \# 562149/2010-4 (PROTAX - OPESC project), and scholarships from Coordenação de Aperfeiçoamento de Pessoal de Nível Superior and Conselho Nacional de Desenvolvimento Científico e Tecnológico to ACM. We are thankful to Tania Köbler Brazil and Rejane Lira (UFBA) for the loan of the material. We also thank to Adriano Kury (MNRJ), Leonardo Azevedo (UERJ), Abel Pérez González (UFRJ) and three anonymous reviewers for their comments on the manuscript.

\section{LITERATURE CITED}

Amorim, A.M.; J.M. Jardim; M.M.M. LoPes; P. Fiaschi; R.A.X. Borges; R.O. Perdiz \& W.W. Thomas. 2009. Angiospermas em remanescentes de floresta montana no sul da Bahia, Brasil. Biota 
Neotropica 9 (3): 313-348. doi: http://dx.doi.org/10.1590/ S1676-06032009000300028.

BREMER, K. 1994. Branch support and tree stability. Cladistics 10 (3): 295-304. doi: 10.1111/j.1096-0031.1994.tb00179.x

Caetano, D.S. \& G. Machado. 2013. The ecological tale of Gonyleptidae (Arachnida, Opiliones) evolution: phylogeny of a Neotropical lineage of armoured harvestmen using ecological, behavioural and chemical characters. Cladistics (2013): 1-21. doi: 10.1111/cla.12009.

DaSilva, M.B. \& R. PinTo-Da-Rocha. 2010. Systematic review and cladistic analysis of the Hernandariinae (Opiliones: Gonyleptidae). Zoologia 27 (4): 577-642.

Dasilva, M.B. \& R. Pinto-DA-Rocha. 2012. Descriptions of Thereza murutinga sp. nov. and Pristocnemis caipira sp. nov., and new records of Caelopyginae (Opiliones: Laniatores: Gonyleptidae). Zootaxa 3317: 25-38.

Felsenstein, J. 1985. Confidence limits on phylogenies: an approach using the bootstrap. Evolution 39 (4): 783-791.

GILTAY, L. 1928. Arachnides nouveaux du Brésil. Bulletin et annales de la Société Entomologique de Belgique 68: 79-87.

Goloboff, P.A \& J.S. FarRis. 2001. Methods for quick consensus estimation. Cladistics 17 (1): S26-S34. doi: 10.1111/j.10960031.2001.tb00102.x

GolobofF, P.; J. FarRis \& K. Nixon. 2008. TNT, a free program for phylogenetic analysis. Cladistics 24 (5): 774-786. doi: 10.1111/j.1096-0031.2008.00217.x

Hadley, A. 2012. CombineZP. Available online at: http:// www.hadleyweb.pwp.blueyonder.co.uk/CZP/News.htm [Accessed: 28/IX/2012].

IBGE, 2012. Manual técnico da vegetação brasileira. Rio de Janeiro, 2nd ed., 276p.

Косн, C.L. 1839. Die Arachniden getreu nach der Natur abgebildet und beschrieben. Nürnberg, C. H. Zeh'schen Buchhandlung, vol. 7, 130p.

KunY, A.B. 1992. The false Cranainae of the Brazilian Atlantic Forest (Opiliones, Gonyleptidae). Tropical Zoology 5 (2): 279-291.

KuRY, A.B. 1994. On the identity of the enigmatic Leptocnema
Koch (Arachnida, Opiliones, Gonyleptidae). Mitteilungen aus dem Zoologischen Museum in Berlin 70 (1): 93-98.

KunY, A.B. 1995. A review of Mitopernoides revalidated (Progonyleptoidellinae) and the synonymy of Mitoperna with Neosadocus (Gonyleptinae) (Arachnida, Opiliones, Gonyleptidae). Papéis Avulsos de Zoologia 39 (8): 201-207.

Kury, A.B. \& R. Pinto-da-Rocha. 2007. Gonyleptidae Sundevall, 1833, p. 196-203. In: R. Pinto-da-Rocha; Machado G. \& G. GiRibet (Eds). Harvestmen: the biology of the Opiliones. Cambridge, Harvard University Press, $\mathrm{X}+597 \mathrm{p}$.

Mello-Leitão, C.F. DE. 1931. Opiliões novos ou criticos. Archivos do Museu Nacional 33: 115-145.

Mello-Leitão, C.F. DE. 1942. Sete novos Laniatores colhidos pelo Snr. A Ruschi no Espirito Santo. Anais da Academia Brasileira de Ciências 14 (2): 159-165.

Nixon, K.C. 2002. WinClada, ver. 1.00.08. Ithaca, Published by the author, available online at http://www.cladistics.com/ aboutWinc.htm [Accessed 29/IV/2011].

Pinto-Da-Rocha, R. \& C. Bragagnolo. 2010. Systematic revision and cladistic analysis of the Brazilian subfamily Sodreaninae (Opiliones: Gonyleptidae). Invertebrate Systematics 24 (6): 509-538. doi: 10.1071/IS10030

PINTO-DA-RochA, R. 2002. Systematic review and cladistic analysis of the Caelopyginae (Opiliones, Gonyleptidae). Arquivos de Zoologia 36 (4): 357-464.

Roewer, C.F.1913 Die Familie der Gonyleptiden de Opiliones Laniatores. [part 2]. Archiv für Naturgeschichte, Abt. A, Original-Arbeiten 79 (5): 257-472.

RoEWER, C.F. 1931. Weitere Weberknechte V. (5. Ergänzung der "Weberknechte der Erde," 1923). Abhandlungen der Naturwissenschaftlichen Verein zu Bremen 28 (2-3): 101-164.

Roewer, C.F. 1943. Über Gonyleptiden. Weitere Webernechte (Arachn., Opil.) XI. Senckenbergiana 26 (1-3): 12-68.

SOARES, B.A.M. 1945. Opiliões de Ubatuba coligidos pelo sr. A. Zoppei. Boletim da Indústria Animal, Nova Série 7 (1-2): 85-96.

Sørensen, W.E. 1884. Opiliones Laniatores (Gonyleptides W.S. Olim) Musei Hauniensis. Naturhistorisk Tidsskrift 14 (3): 555-646.

Submitted: 29.XI.2012; Accepted: 28.III.2013.

Editorial responsibility: Alessandra Rung 